\title{
Brush Control on Sandy Rangelands in Central Alberta
}

ARTHUR W. BAILEY AND HOWARD G. ANDERSON

\section{Abstract}

Balsam poplar, aspen, and willows that had invaded subirrigated sandy rangeland were treated with (1) prescribed spring burning, (2) the herbicide 2,4-D ester, and (3) prescribed burning followed by 2,4-D ester. After 5 years, burning and spraying had reduced brush the most. Brush reinvasion was occurring rapidly on all treated areas. Stand openings of about one quarter hectare in an 8 meter high poplar forest resulting from these treatments did persist for at least 5 years. Treatments were effective enough to lower the forest cover and in some cases increase forage production. Repeated burning and spraying substantially reduced the density of reinvading woody suckers.

The presence of woody plants on rangeland has long been of concern to the land managers interested in increasing forage production. Woody species encroachment has been attributed to fire control, overgrazing, and farm abandonment (Friesen et al. 1965) although climatic cycles have also been influential (Bailey and Wroe 1974). Forage production could be increased if woody vegetation was reduced. The depressing effect of woody plants on grasses has been demonstrated (Bailey and Wroe 1974; Whysong and Bailey 1975).

Methods of brush control have focused upon mechanical means, prescribed burning and herbicides, or some combination of these. Mechanical removal of aspen forest and replacement by forages has not been always successful in arresting aspen suckering (Pringle et al. 1973). Burning of aspen cover is not always successful because of the discontinuous coverage of fuels and the difficulty in obtaining suitable burning conditions (Perala 1974). A single fire also fails to control aspen suckering (Horton and Hopkins 1966). However under appropriate conditions, and in conjunction with spraying, prescribed burning may be an effective range improvement tool. Foliar applications of herbicides have been used

Authors are professor and research associate, Department of Plant Science, University of Alberta, Edmonton, Alberta.

This research was supported by an Alberta Agricultural Research Trust grant and a National Research Council of Canada grant to the senior author.

Manuscript received July 19, 1977. with some success on aspen in western Canada (Bailey 1972; Bowes 1976) indicating the usefulness of continued research in this area.

The experiments reported here were designed to determine the magnitude and duration of the effects of prescribed burning, herbicide treatment, and a combination of the two on species composition, density of woody stems, and herbage production of a mix poplarwillow (Populus-Salix) forest which had encroached on subirrigated sandy ranges dominated by a baltic rushKentucky bluegrass (Juncus balticus ${ }^{1}$ Poa pratensis) grassland.

\section{Methods}

The study area was located on the eastern shoreline of Beaverhill Lake, approximately $80 \mathrm{~km}$ east of Edmonton, Alta. The lake level has receded considerably during the past 60 years exposing new soil. Baltic rush and Kentucky bluegrass colonized the uplands but were invaded by balsam poplar (Populus balsamifera), aspen poplar $(P$. tremuloides), and willows (Salix) spp.). Average maximum heights in 1976 were 8 $\mathrm{m}$ for poplars and $2 \mathrm{~m}$ for willows. Grassland openings were dominated by baltic rush and Kentucky bluegrass. The substratum consists of approximately $4 \mathrm{dm}$ of sand overlying a heavy clay subsoil. The water table occurs at approximately $8 \mathrm{dm}$. The surface configuration of the land is marked by a series of berms and bars with relief differences of less than $1 \mathrm{~m}$. Drainage and sand texture differences are apparent

\footnotetext{
1 Nomenclature follows Moss (1959).
}

due to the micro-relief.

An experiment was established in 1971 in a 15-year-old stand of aspen and balsam poplar. Understory vegetation included the willows Salix bebbiana, S. discolor, $S$. petiolaris, $S$. serissima, baltic rush, Kentucky bluegrass and slender wheatgrass (Agropyron trachycaulum). The common forbs were wild strawberry (Fragaria virginiana) and many flowered aster (Aster hesperius). Four treatments were established within each of four replicates: (1) control, (2) burn, (3) spray, and (4) a burn and spray combination. Prescribed burning was conducted on May 18, 1971. About 1/4 hectare was burned in each replicate. All spraying was carried out on July 5, 1971. The ester of 2,4-D was applied at $2.2 \mathrm{~kg} / \mathrm{ha}$ (2 lb/acre) in 1:14 diesel: water ratio at 157 $1 /$ ha (14 gal/acre). Within each treatment eight permanent plots were randomly located. Data was collected three times from 128 plots.

Canopy coverage (7-part scale) of each species (Daubenmire 1968) and density of live, injured, and dead woody stems by d.b.h. (diameter breast high $1.4 \mathrm{~m}$ above ground) class were recorded in August of 1971, 1972, and 1976. Sizes of quadrats were $0.1 \mathrm{~m}^{2}$ for canopy cover and $0.84 \mathrm{~m}^{2}$ for density of woody stems. Herbage production was assessed by clipping vegetation from $0.28 \mathrm{~m}^{2}$ quadrats in August 1972 .

Woody density data were sorted into the following species groups: aspen poplar, balsam poplar, willows. Two size categories were used for each: (1) those less than $1 \mathrm{~m}$ high were classed as suckers regardless of origin; and (b) those greater than $1 \mathrm{~m}$ were classed as stems. Data were basically examined by analysis of variance. A randomized complete block design facilitated a two-way analysis of variance. Duncan's new multiple range test $(P<0.05)$ was used to compare means of canopy coverage, woody density and herbage production.

A preliminary unreplicated experiment was initiated May 11, 1968, by burning a 2-ha area. The burned area was sprayed August 7,1968 , with a mixture of 1.7 $\mathrm{kg} / \mathrm{ha}(1.5 \mathrm{lb} / \mathrm{acre})$ 2,4-D ester and 0.14 $\mathrm{kg} / \mathrm{ha}$ ( $2 \mathrm{oz} / \mathrm{acre}$ ) picloram (Tordon $22 \mathrm{k}$ ) in $78 \mathrm{l} / \mathrm{ha}$ (7 gal/acre) of water. The area was reburned in May, 1971, accidentally burn- 
ing the control area as well as the treatment area. The original treatment area was resprayed on July 6, 1971, with $2.2 \mathrm{~kg} / \mathrm{ha} \mathrm{(2}$ $\mathrm{lb} /$ acre) $2,4-\mathrm{D}$ ester in a 1:14 diesel:water mixture at 157 1/ha (14 gal/acre). Data were collected in 1968, 1971, and 1976 using the procedures already described for the main experiment.

\section{Results}

Canopy cover of aspen and willows was reduced by the brush control treatments (Table 1). After 5 years, the burning and spraying treatment was most consistent in reducing the cover of woody species. This method did not cause long-term detrimental effects to herbaceous vegetation. Wild strawberry expanded under this treatment. Short-term changes in herbaceous vegetation did occur. Kentucky bluegrass and wild strawberry were reduced by burning 1 year after treatment.

One year after treatment, rush, grass, and forb production was higher on burned areas $(1,150 \mathrm{~kg} / \mathrm{ha})$ than on control areas $(470 \mathrm{~kg} / \mathrm{ha})$. There was no change in forage production on other treated areas. The fire consumed about $2,300 \mathrm{~kg} / \mathrm{ha}$ of litter. Litter production averaged $3,050 \mathrm{~kg} / \mathrm{ha}$ in unburned areas and $750 \mathrm{~kg} / \mathrm{ha}$ in burned areas.

The effect of spraying on live stems was not obvious until 1 year after treatment (Table 2). Suckers started to emerge in 1972 but the residual effect of the herbicide was evident for

Table 1. Canopy cover $(\%)$ of common species 5 years after brush control treatments.

\begin{tabular}{|c|c|c|c|c|c|c|}
\hline \multirow[b]{2}{*}{ Treatment } & \multicolumn{4}{|c|}{ Species } & \multirow[b]{2}{*}{$\begin{array}{l}\text { Kentucky } \\
\text { bluegrass }\end{array}$} & \multirow[b]{2}{*}{$\begin{array}{c}\text { Wild } \\
\text { strawberry }\end{array}$} \\
\hline & Balsam & Aspen & Willows & $\begin{array}{l}\text { Baltic } \\
\text { rush }\end{array}$ & & \\
\hline Control & $30 a^{\prime}$ & $48 a$ & $27 \mathbf{a}$ & $35 \mathrm{~b}$ & $21 \mathrm{a}$ & $0.4 \mathrm{~b}$ \\
\hline Sprayed & $31 \mathbf{a}$ & $15 b$ & $7 \mathrm{~b}$ & $45 \mathrm{ab}$ & $20 \mathrm{a}$ & $2 \mathrm{ab}$ \\
\hline Burned & $28 \mathrm{a}$ & $5 c$ & $9 \mathrm{ab}$ & $60 \mathrm{a}$ & $11 a$ & $2 a b$ \\
\hline $\begin{array}{l}\text { Burned and } \\
\text { sprayed }\end{array}$ & $18 \mathrm{a}$ & $10 \mathrm{bc}$ & $3 b$ & $43 \mathrm{ab}$ & $18 \mathrm{a}$ & $4 a$ \\
\hline
\end{tabular}

Means tollowed by the same letter in vertical sequence within 1 species are not significantly different $(P<0.05)$.

willows. Five years after treatment, only willows had lower stem densities in sprayed areas.

The effect of burning was apparent several months after treatment. Burning alone resulted in a mortality of about 79,83 , and $96 \%$ for balsam, aspen, and willow stems, respectively. Suckering occurred soon after the fire. By August 1971, there were about as many balsam, aspen, and willow suckers on the burned areas as there were suckers and stems on the control area. Suckering continued in 1972 for all species. Most balsam suckers grew in 1972 rather than 1971. Fewer aspen and willow suckers established in 1972. Five years after treatment, there were more balsam stems and the same number of aspen and willow stems in burned and control areas.

Burning followed 6 weeks later by spraying was generally the most effec- tive treatment by the end of the 1972 growing season. By 1972, the mortality of live stems was about 96,88 , and $94 \%$ for balsam, aspen and willows, respectively. There were fewer balsam and willow suckers in 1972 in burned and sprayed areas than in burned only areas. After 5 years only willows had fewer stems than control areas.

Burning followed by spraying was most effective in causing a shift in distribution of the tree size classes 5 years after treatments (Table 3). All treatments stimulated suckering but a follow-up treatment reduced suckers and small stems.

A preliminary experiment without replication was initiated in 1968. Most woody stems were killed (Fig. 1) but a new forest could develop from the woody sprouts (Fig. 2). Repeated treatments did reduce density of willow stems (Table 4). The mean density of

Table 2. Density of woody stems and woody suckers $\left(\mathrm{No} . / 10 \mathrm{~m}^{2}\right)$ in four treatments the year of treatment (1971), 1 year (1972) and 5 years $(1976)$ afterward.

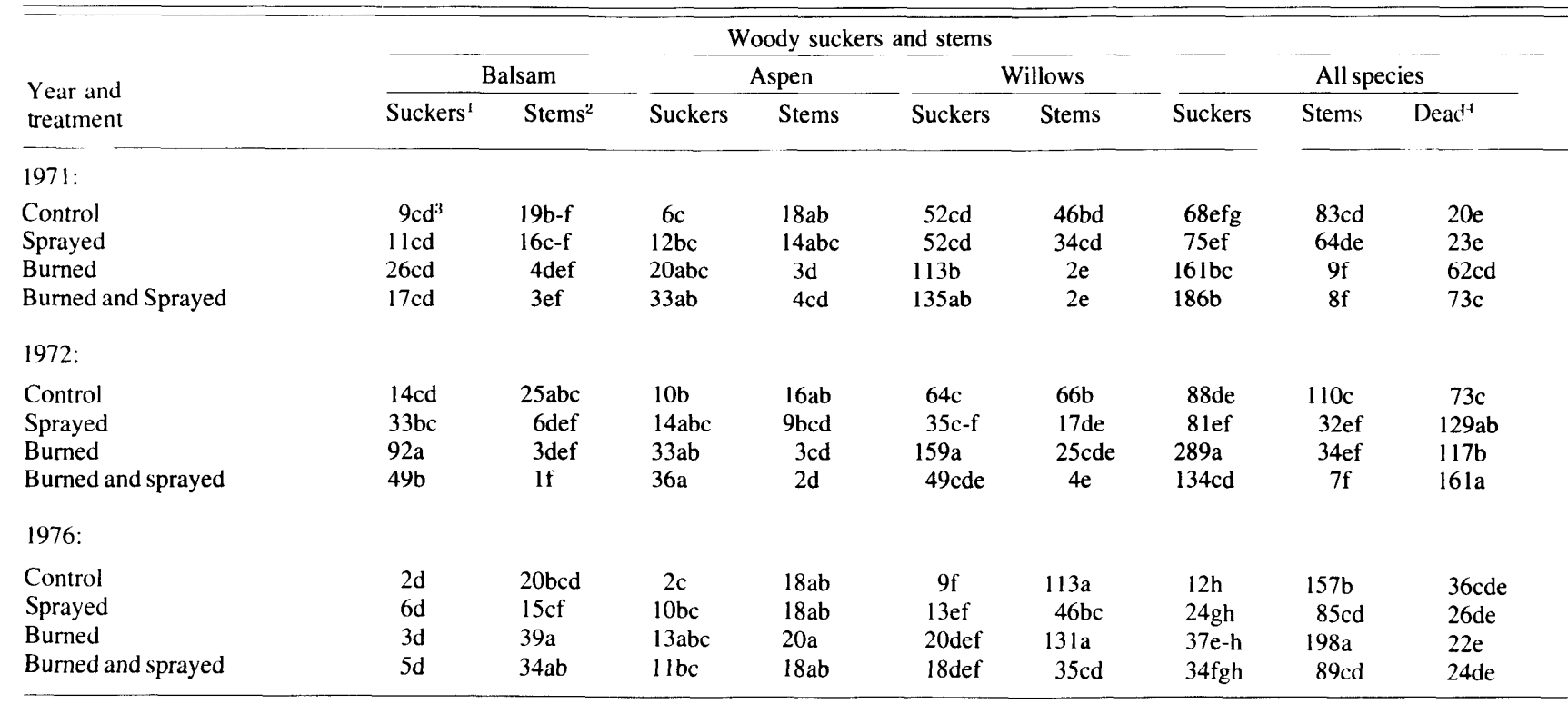

Less than $1 \mathrm{~m}$ high, commonly shoots of the current year.

'All stems one or more years old greater than $1 \mathrm{~m}$ high.

"Means followed by the same letter in vertical sequence are not significantly different $(P<0.05)$.

Includes stems and suckers. 
balsam and aspen stems averaged onehalf of the 1968 control. More suckers were continuing to sprout in the treated areas in 1976 than were present in the 1968 control.

\section{Discussion}

Brush control treatments used have been effective in temporarily checking the forest advance. Forage production was increased in some areas and it was demonstrated that the forb wild strawberry can expand after treatment with 2,4-D ester as reported by Hilton and Bailey (1974). Burning followed by spraying of woody sucker regrowth with 2,4-D ester showed promise of being an effective means of brush control. However, spraying should not be done just 6 weeks after burning. Not a long enough period of time has passed to permit sprouting of most suckers. Sprouting was observed to continue after the spraying of July 5, 1971, in both 1971 to 1972 . Balsam poplar suckers resprouted more slowly than aspen or willow, essentially avoiding the herbicide. Spraying should have been done the second year to kill the sprouts which established in 1971 and 1972.

The reinvasion of balsam and aspen poplar on treated plots was probably greater than under field scale opertions. Both poplar species grew as a clone. Many stems are connected together by the root system. Brush control treatments applied to $1 / 4-$ to $1 / 2$-hectare areas can be very effective but they do not last because of rapid lateral reinvasion. Only the willows grew as distinct individuals. The brush control treatment that included herbicide laster longer on willows than on either poplar species.

Minor site differences apparently caused differential tree survival and differential reinvasion of woody suckers. Berms and bars occurred throughout the four blocks. Balsam and aspen poplar were dense on old berms or bars that varied from $2 \mathrm{dm}$ to $1 \mathrm{~m}$ in elevation above the surrounding landscape. Soils of berms and bars were droughty because they had nearly pure sand and were deeper to clay. There was very little understory fuel. More trees survived the fire because of the scanty fuels. Most woody suckers sprouted after the herbicide application.

Repeated brush control treatments caused a gradual decline in density of woody stems. However, all brush species studied were alive and reestablishing 5 years after the second treatment.

Grazing ranged from none to light on

Table 3. Diameter size class distribution of live woody stems $\left(\right.$ No. $\left./ 10 \mathrm{~m}^{2}\right) 5$ years after treatment.

\begin{tabular}{|c|c|c|c|c|c|c|}
\hline \multirow[b]{2}{*}{ Treatment } & \multirow[b]{2}{*}{ Suckers } & \multicolumn{5}{|c|}{ Stem diameter class $(\mathrm{cm})$} \\
\hline & & 1 & 4 & 6 & $9+$ & Total \\
\hline Control & 12 & 157 & 3 & 2 & 1 & 174 \\
\hline Sprayed & 24 & 85 & 3 & 1 & 1 & 114 \\
\hline Burned & 38 & 198 & 1 & 1 & 1 & 237 \\
\hline Burned and sprayed & 34 & 89 & 2 & 0 & 0 & 125 \\
\hline
\end{tabular}

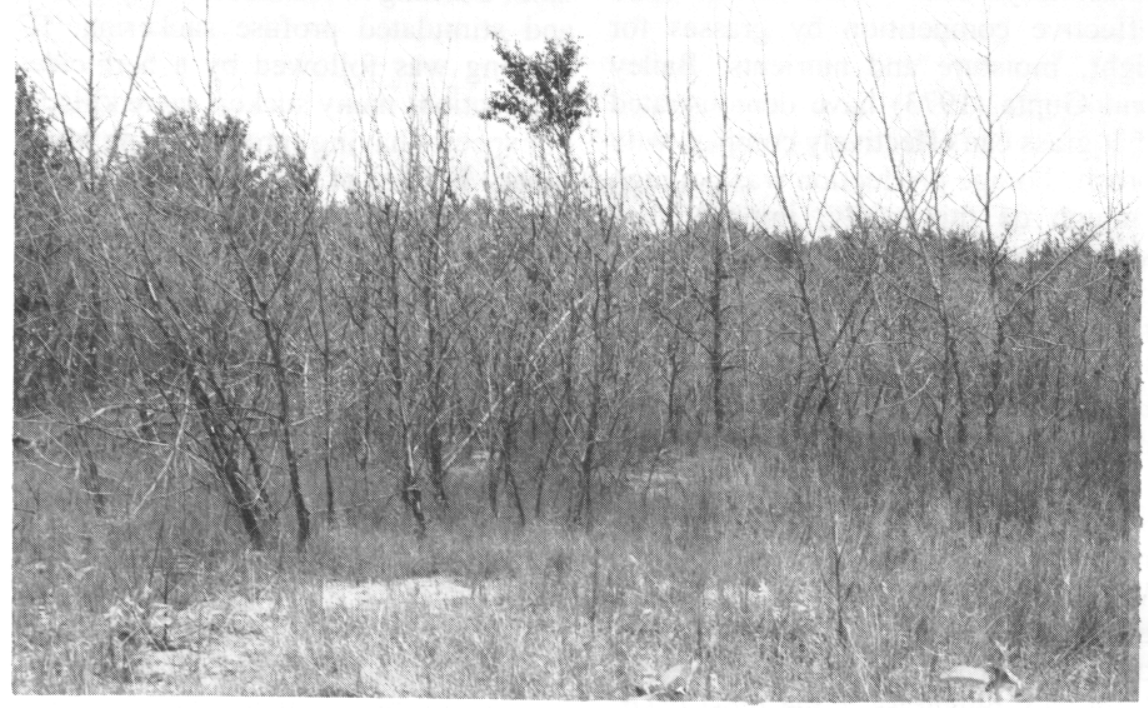

Fig. 1 A poplar-willow forest burned and sprayed twice and photographed one year after second set of treatments.

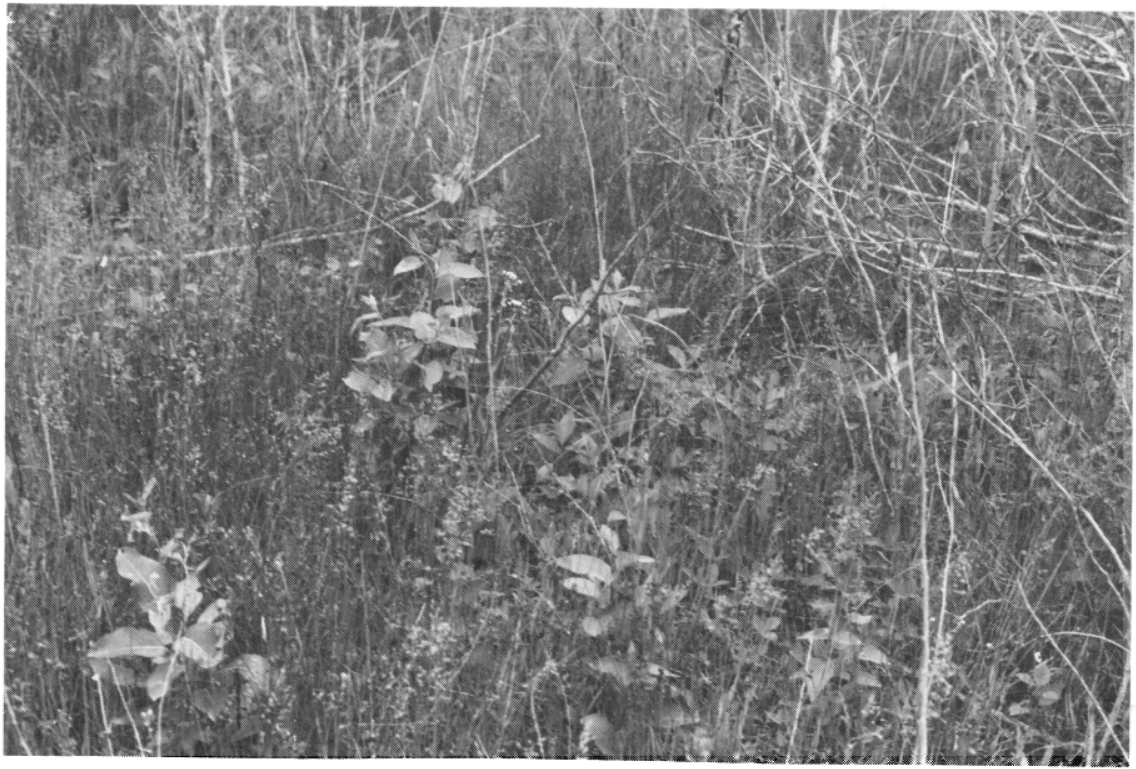

Fig. 2 Willow and poplar suckers one year after treatment. There is sufficient density to quickly reduce forage production under a new forest canopy. 
Table 4. Density of woody plants $\left(\mathrm{No} . / 10 \mathrm{~m}^{2}\right)$ over an 8 -year period on control and burned plus sprayed treatment areas.

\begin{tabular}{|c|c|c|c|c|}
\hline Species & Size class & $\begin{array}{c}\text { Control } \\
1968\end{array}$ & $\begin{array}{c}\text { Burned }+ \\
1968\end{array}$ & $\begin{array}{c}\text { Sprayed } \\
1976\end{array}$ \\
\hline & & $n=30$ & $n=30$ & $\mathrm{n}=30$ \\
\hline \multirow[t]{2}{*}{ Balsam } & Suckers & $2 c^{2}$ & $64 a$ & $12 b$ \\
\hline & Live stems ${ }^{1}$ & $29 a$ & $2 b$ & $17 \mathrm{a}$ \\
\hline \multirow[t]{2}{*}{ Aspen } & Suckers & $4 c$ & $62 a$ & $28 \mathrm{ab}$ \\
\hline & Live stems & $37 \mathrm{a}$ & lb & $20 a$ \\
\hline \multirow[t]{2}{*}{ Willows } & Suckers & $10 \mathrm{c}$ & $294 a$ & $162 b$ \\
\hline & Live stems & $141 \mathrm{a}$ & $1 \mathrm{c}$ & $23 b$ \\
\hline \multirow[t]{3}{*}{ All species } & Suckers & $15 c$ & $423 a$ & $203 b$ \\
\hline & Live stems & $216 a$ & $3 \mathrm{c}$ & $62 b$ \\
\hline & Dead stems & $0 \mathrm{c}$ & $193 a$ & $7 \mathrm{~b}$ \\
\hline
\end{tabular}

'Includes all stems at least $1 \mathrm{~m}$ high.

? Means lollowed by the same letter in horizontal sequence are not signilicantly diffeent $(P<0.05)$.

understory. This would permit more effective competition by grasses for light, moisture and nutrients. Bailey and Gupta (1973) have demonstrated that grass can effectively compete with brush. Forage production was not high enough on this sandy, impoverished site for the grass to provide much competition to brush (Fig. 1). However, forage competition with brush was likely very important in the studies of Bailey (1972) and Bowes (1975) in reducing brush density and growth rate.

Curtis and Partch (1948) demonstrated that Kentucky bluegrass was reduced more by May burning in Wisconsin than by March or October burning. On our sandy lakeshore, fall burning may be a better time since Kentucky bluegrass is the most desirable forage species.

The experiment has provided preliminary results on the effectiveness and duration of brush control treatments on sandy, subirrigated range- land. Burning killed most woody stems and stimulated profuse suckering. If burning was followed by a herbicide application, many suckers were killed. For species having sprouts arising from roots, killing of the suckers should result in decreased food reserves in the root system. The effects of fire on aspen regeneration are not conclusive as some studies have shown an increase in stem density (Perala 1974) whilc others have shown a decrese (Buckman and Blankenship 1965). However, burning is a desirable option because of its low cost and its ability to kill woody would be achieved by burning at about 4-year intervals. Reburning has a number of problems including the low quantities of fuels in poplar stands and high fuel moisture levels (Perala 1974). However, good burning conditions are needed only once every 4 years, a situation that is realistically attainable. stems. Where this is the case it is suggested that most effective results

\section{Literature Cited}

Bailey, Arthur W. 1972. Forage and woody sprout establishment on cleared, unbroken land in central Alberta. J. Range Manage. 25: 119-112.

Bailey, Arthur W., and R.K. Gupta. 1973. Grass-woody plant relationships. Can. J. Plant Sci. 53: 671-676.

Bailey, Arthur W., and R.A. Wroe. 1974. Aspen invasion in a portion of the Alberta Parklands. J. Range Manage. 27: 263-266.

Bowes, G.G. 1975. Control of aspen and prickly rose in recently developed pastures in Saskatchewan. J. Range Manage. 28: 227-229.

Bowes, Garry. 1976. Control of aspen poplar, and prickly rose by picloram alone and in mixtures with 2,4-D. J. Range Manage. 29: 148-150.

Buckman, Robert E., and Lytle H. Blankenship. 1965. Repeated spring prescribed burning reduces abundance and vigor of aspen root suckering. J. Forest. 63: 23-25.

Curtis, J.T., and M.L. Partch. 1948. Effect of fire on the competition between blue grass and certain prairie plants. Amer. Midl. Natur. 39: 437-443.

Daubenmire, R. 1968. Plant communities. Harper \& Row. New York. 300p.

Friesen, H.A., et al. 1965. Brush control in western Canada. Can. Dep. Agr. Pub. 1240. $26 \mathrm{p}$.

Hilton, J.E., and A.W. Bailey. 1974. Forage production and utilization in a sprayed aspen forst in Alberta. J. Range Manage. 27: 375-380.

Horton, K.W., and E.J. Hopkins. 1966. Influence of fire on aspen suckering. Can. Dep. Forest Pub. 1095. 19p.

Moss, E.H. 1959. Flora of Alberta. Univ. Toronto Press, Toronto. 546p.

Perala, Donald A. 1974. Repeated prescribed burning in aspen. U.S. Dep. Agr. Forest Serv., North Central Forest Res. Sta., Res. Note NC-171. St. Paul, Minn. 4p.

Pringle, W.L., C.R. Elliott, and J.L. Dobb. 1973. Aspen regrowth in pastures of the Peace River region. J. Range Manage. 26: 260-262.

Whysong, Gary L., and Arthur W. Bailey. 1975. Production and nitrogen content of herbage in a silverberry (Elaeagnus commutata) community compared to adjacent grassland and forest communities. Can. J. Plant Sci. 55: 801-808. 